Journal of Social Science 3(4): 164-171, 2007

ISSN 1549-3652

(C) 2007 Science Publications

\title{
Women Empowerment through Participation in Aquaculture: Experience of a Large-scale Technology Demonstration Project in Bangladesh
}

\author{
${ }^{1}$ M. Hammadur Rahman and ${ }^{2}$ Kazi Naoroze \\ ${ }^{1}$ Bangladesh Agricultural University, Mymensingh, Bangladesh \\ ${ }^{2}$ Bangladesh Agricultural Development Corporation, Dhaka, Bangladesh
}

\begin{abstract}
The paper investigated rural women's empowerment through participation in aquaculture activities within a large scale demonstration project in Bangladesh. The paper is based on farm level data collected from 200 women in two districts of Bangladesh. A questionnaire was used for the purpose of data collection and data gathering spanned a period of four months, (September to December) in 2004. The findings show that women in the study area gained a significant level of empowerment during the course of their participation in the aquaculture program. The extent of their empowerment was positively and significantly correlated with their education, extension media contact and exposure to training, as well as their knowledge and participation in aquaculture. Other factors, such as age, family size, family farm size, area under aquaculture, and annual family income did not show any significant relationship with the extent of a woman's empowerment through participation in aquaculture.
\end{abstract}

Keywords: Women, empowerment, aquaculture, participation, Bangladesh, DSAP

\section{INTRODUCTION}

Women constitute nearly half of the world's total population. They are the co-builders of civilization yet they are underprivileged in many parts of the globe, especially in developing countries such as Bangladesh $^{[1]}$. The life of women in Bangladesh is dominated by a patriarchal social system. Such a system upholds a rigid division of labor that controls a women's mobility, as well as the roles and responsibilities she may take on. Traditionally, a Bangladeshi woman derives her status from her family and her primary role is the maintenance of that family as a social institution and economic entity. Most importantly, through childbearing and child rearing, she ensures the existence of succeeding generations. Disparities exist between men and women in education, health, employment and income opportunities, control over assets, personal security and participation in the political process.

Despite various different national and international programs aimed at increasing the standing of women in Bangladesh, their status is still far below that hoped for by many. Indeed, according to the United Nations Gender-related Development Index (GDI), Bangladesh ranked $105^{\text {th }}$ out of a total of 177 countries worldwide $^{[2]}$.
Men traditionally dominate women in all spheres of life in Bangladesh, with poor women in rural areas having the least power. Women have few rights, little choice about the course of their lives, and very few opportunities to change their situation. They also have little or no access to people or positions of influences. They are mostly illiterate and often have the least to eat. In addition they are often deserted if their husband cannot find work in the local area and has to move away to earn a wage ${ }^{[3]}$. Bangladeshi women are therefore disadvantaged and less empowered than men and this definitely limits the country's ability to achieve its full potential.

However, despite all of the above, women do play a significant role in agricultural activities in Bangladesh. This includes crop production and processing, post-harvest operations, livestock husbandry, aquaculture and agro-social forestry, although, they must do all of these in addition to their day to day, household related, work. Nevertheless in Bangladesh and elsewhere in the developing world, women's involvement in aquaculture is increasing. Indeed both the public and private sectors are increasingly emphasizing the need for the greater involvement of women in this industry. A large number of women are also participating in aquaculture through

Corresponding Author: $\quad$ M. Hammadur Rahman, Department of Agricultural Extension Education, Bangladesh Agricultural University, Mymensingh - 2202, Bangladesh, Tel: (88 1) 55695Ext.2480, Fax: (88 91) 55810 
projects run by non-government organizations (NGOs) and various government backed schemes.

The WorldFish Center, a member of CGIAR (Consultative Group on International Agricultural Research), is working for the development of the fisheries sector in Bangladesh. In 2000 the Center undertook the USAID (United States Agency for International Development) supported 'Development of Sustainable Aquaculture Project' (or DSAP), the major thrusts of which were to implement aquaculture demonstrations and to put unused and/or underused seasonal and perennial ponds and rice fields into profitable use. The objective was to accomplish these by using methods that would be both affordable and acceptable to resource poor households in rural areas of Bangladesh. The DSAP approach aimed to make cooperating farmers (and implementing NGOs) self sustainable, so that aquaculture practices and development can continue in rural areas after the withdrawal of the project7s support. The outreach activities of the project are being implemented through 35 partner NGOs in 37 districts of Bangladesh ${ }^{[4]}$.

The DSAP has a unique strategy for the development of small scale aquaculture. This is the holistic approach, which encourages the involvement of all family members of the participants, especially women. Thus it is hoped that, through this intervention, the women of Bangladesh will gradually increase their involvement in aquaculture, which will eventually bring a wide range of benefits and lead to their empowerment within families as well as society in general. For this to happen it is of utmost important to formulate an appropriate strategy for increasing their participation in income generating activities (IGAs) particularly in aquaculture. This will necessitate a changing of the current nature of both women's participation in aquaculture as well as associated issues, such as its impact on their livelihoods. Investigations of these issues have become an important topic in Bangladesh in recent years. This paper therefore aims to determine the increase of women's empowerment through participation in aquaculture programs under the DSAP intervention. The study further focuses on how the extent of women's empowerment through participation in aquaculture is related to other factors.

\section{MATERIALS AND METHODS}

Study area and sample: The study was conducted in the Sherpur and Kishoreganj districts of Bangladesh. The DSAP has a number of partner NGOs in these areas which are disseminating appropriate aquaculture technologies among the local fish farmers. Two such partner NGOs, the Foundation for Human Development (FHD) and Centre for Rural and Environment Development (CRED), were selected for this study, while female members of the families of farmers participating in the project were the target population. The women were selected for participation in the project providing that they had been involved in aquaculture activities under the DSAP intervention for at least three years. A total of 390 rural women were identified in the study area that fulfilled that criteria and from this group a sub sample of 200 women were randomly selected for the present study.

Data collection: In order to collect the data required for the study, a structured questionnaire was developed. The draft questionnaire was tested in a small subsample of 20 women in the study area. The questionnaire was then modified as a result of feedback from this test. Test-retest reliability was conducted to determine the reliability of the components of the survey (the reliability coefficient ranged from 0.78 to 0.89 ) and a number of referees from relevant disciplines were employed to check the content validity of the questionnaire. Data were collected from the targeted rural women during the months of September to December, 2004 via face-to-face interviews.

Measurement of women empowerment: A large number of studies are available on empowerment measuring techniques. After a careful study of the available literature $[1,5,6,7,8]$, five measures of empowerment were selected for this study. These were: a woman's decision making ability within the family, spending ability, cosmopoliteness, social participation and access to assets and resources. A number of items were arranged under each of these five measurements and the women taking part in the survey were asked to indicate their perceived extent of empowerment along a 4-point continuum, taking into account their situations before and after participation in the DSAP aquaculture program.

The items included for measuring the women's decision-making ability within a family were: the education of children, family health issues, the celebration of social and religious events, choice of guests and entertainment at social functions, selecting and using family planning methods, giving loans to others, homestead agricultural production, livestock and poultry buying and selection, constructing and repairing of houses, and daily family household expenditure.

The spending ability of a woman was measured by ten points related to the ability of her financial authority. These included: buying household furniture 
and other items, providing financial help to others, expenditure on medicare and health, buying gifts for social functions, making donations to charity, lending and borrowing money, spending money on income generating activities, spending income from family sources, purchasing and selling of land and other assets, and spending money on children's education.

The cosmopoliteness of a woman was defined as her general orientation outside her close social system ${ }^{[9]}$. A social system was taken to be 'any social structure composed of social interactions and cultural factors, in which the members interact more with members than with non-members when participating in the organization as an on-going concern ${ }^{\text {, }[10]}$. A respondent's cosmopoliteness was measured by adding up the number of times she reported having visited the market place, friends and relatives houses outside the home village, the upazila (sub-district) headquarters, the neighboring upazilas, the local district headquarters, other districts, the capital city and the local fisheries office.

Social participation included seven social and community activities, namely; participation in social functions such as marriage and birthday celebrations, helping neighbors in crisis situations, working with people in emergency situations (such as natural disasters), participation in village meetings and arbitrations, participation and organization of cultural programs, arbitration in the conflicts of neighbors and family, and casting votes in local and national elections without outside interference.

Access to assets and resources included the following seven items; access to a bank (e.g. having their own bank account), access to institutional credit, ability to contact public services (health, nutrition, farming etc.), access to family income and resources, access to valuable instruments and machinery, access to farm management and budgeting, and access to inherited properties.

The empowerment score of a respondent in a particular measure of empowerment was computed by adding the scores obtained in all items in that class. A summary of the measuring system of all five measures of empowerment is presented in table 1.

The overall empowerment score of a respondent was determined by adding the total scores from all five components, which could range from 0 to 126 , with 0 indicating no empowerment and 126 indicating the highest level of empowerment. In order to make a comparison among the five measures of empowerment, a unit score was computed for each using the following formula:

Unit empowerment score $=\frac{\text { Mean score of a particular dimension }}{\text { Maximum possoble score of the dimension }}$

Measurement of other variables: Ten variables were selected to determine their relationship with rural women's empowerment through participation in aquaculture. The variables were: age, level of education, family size, family farm size, area under aquaculture, extension media contact, training exposure, knowledge in aquaculture, family annual income, and level of participation in aquaculture activities.

The age of a respondent was defined as the period of time from her birth to the time of the interview (expressed in years). Her education level was taken to be the highest year of schooling completed. Family size was measured by the number of individuals who lived in the same household and ate together. Family farm size indicated the cultivable land area owned by the members of a respondent's family, while the area under aquaculture referred to the total area of land/pond under aquaculture.

In measuring the extension media contact of a respondent, 17 items were considered. Among these, eight related to individuals (Fisheries Officer, Agriculture Extension Officer, Livestock Officer, Field Extension Agent, NGO officer, NGO field agent, health agent, and farm input dealer), four to groups (method demonstration meetings, result demonstration meetings, group discussion and training sessions), and the remaining five related to mass contact (visiting agricultural fairs and exhibitions, watching farm films, reading agricultural leaflets and books, listening to farm radio programs and watching farm television programs). A respondent's extent of contact to a particular media was determined through the checking one of the following options in the survey: 'frequently,' 'occasionally,' 'rarely,' and 'not at all,' scores were assigned to these responses as 3, 2, 1 and 0 respectively. The scores obtained by a respondent in all items were added together to compute the overall extension contact score.

Training exposure referred to the total number of days that a respondent received agricultural related training in the previous five years. Their knowledge in aquaculture was measured by asking a number of questions on different aspects of aquaculture. The scores obtained from all questions were added together to determine a respondent's total knowledge score. The annual family income was defined as the total earnings of a respondent and the members of her family from all farm or non-farm sources of occupations during last calendar year. 
Table 1: Dimensions of empowerment and their measurement

\begin{tabular}{lclc}
\hline \multicolumn{1}{c}{$\begin{array}{c}\text { Empowerment } \\
\text { dimensions }\end{array}$} & $\begin{array}{c}\text { Items } \\
\text { used }\end{array}$ & \multicolumn{1}{c}{ Responses and assigned scores } & $\begin{array}{c}\text { Possible score } \\
\text { range }\end{array}$ \\
\hline $\begin{array}{l}\text { Decision making ability } \\
\text { in family }\end{array}$ & 10 & $\begin{array}{l}\text { Full influence (3), Moderate influence (2), Low } \\
\text { influence (1), No influences (0) }\end{array}$ & $0-30$ \\
Spending ability & 10 & $\begin{array}{l}\text { Full ability (3), Partial ability (2), } \\
\text { Low ability (1), No ability (0) }\end{array}$ & $0-30$ \\
Cosmopoliteness & 8 & $\begin{array}{l}\text { Frequently (3), Occasionally (2), Rarely (1), Not at } \\
\text { all (0) }\end{array}$ & $0-24$ \\
Social participation & 7 & $\begin{array}{l}\text { Frequent participation (3), Occasional participation } \\
\text { (2), Seldom participation (1), No participation (0) }\end{array}$ & $0-21$ \\
$\begin{array}{l}\text { Access to assets and } \\
\text { resources }\end{array}$ & 7 & $\begin{array}{l}\text { Full access (3), Partial access (2), Low access (1), } \\
\text { No access (0) }\end{array}$ & $0-21$ \\
\hline
\end{tabular}

A women's level of participation in aquaculture was measured by their extent of participation in ten common aquaculture practices. A 4-point rated scale was used where a respondent was asked to indicate her extent of participation in a particular aquaculture activity. The possible scores were 0 for 'no participation,' 1 for 'rare participation,' 2 for 'occasional participation' and 3 for 'frequent participation.' The total participation score of a rural woman was obtained by summing her scores in all the ten selected aquaculture activities and so could range from $0-30$, with 0 indicating no participation and 30 indicating the highest level of participation.

Statistical analysis: Besides the conventional statistical measures such as mean, standard deviation and percentage, a number of tests were performed. A paired sample $\mathrm{t}$-test was used to test the differences between the empowerment scores of women 'before' and 'after' taking part in the DSAP project. Pearson's product moment correlation coefficient (r) was computed to examine significance of the relationships between women's empowerment through participation in aquaculture and selected independent variables. Multiple regression analysis was used to identify the most significant variables which explained the variation of concerned variables.

\section{RESULTS AND DISCUSSION}

Empowerment of women: The empowerment of women through their participation in aquaculture was ascertained on the basis of the five points mentioned earlier. Table 2 shows the average empowerment scores and associated unit empowerment scores of the respondent women in all five dimensions before and after their involvement in the DSAP aquaculture program.

The data reveal that women in the study achieved a significant level of empowerment in all dimensions measured after involvement in the DSAP aquaculture program. However, although they improved, the unit scores indicate that the empowerment of the respondents in most of the dimensions, (with the exception of family decision making) seemed to remain relatively low. It could be concluded from this result that the involvement of women in aquaculture activities does significantly improve their empowerment levels but not by as much as was hoped at the start of the project.

Comparison between the measures of empowerment. Stepwise multiple regression analysis presented in table 3 shows that, of the five selected measures of empowerment, 'access to assets and resources' alone was responsible for $59.8 \%$ of the variation in overall empowerment, whilst 'decision making ability' predicted $25 \%$ of the variation. Thus, almost $85 \%$ of the variation of the overall empowerment score is expressed by these two important dimensions. Development agencies, in both the public and private sectors, who are working in gender sensitive issues, should give proper emphasis to this issue before launching any program related to the empowerment of women.

Categories of women according to empowerment status. The total empowerment score of a respondent was obtained by summing the scores obtained from all five measures of empowerment. Possible scores ranged from 0 to 126 . However, the obtained scores ranged from 7 to 94 before participation in aquaculture activities, and 11 to 97 afterwards. The respondents were classified into four categories on the basis of their empowerment scores, as shown in table 4. 
Table 2: Scores obtained by the respondent rural women in five dimensions of empowerment before and after their participation in aquaculture program $(\mathrm{N}=200)$

\begin{tabular}{|c|c|c|c|c|c|c|}
\hline \multirow[t]{2}{*}{$\begin{array}{l}\text { Empowerment } \\
\text { dimension }\end{array}$} & \multirow{2}{*}{$\begin{array}{c}\text { Possible } \\
\text { score } \\
\text { range }\end{array}$} & \multicolumn{2}{|c|}{$\begin{array}{c}\text { Mean and standard } \\
\text { deviation }\end{array}$} & \multicolumn{2}{|c|}{ Unit score } & \multirow{2}{*}{$\begin{array}{l}\mathrm{t} \text {-value for } \\
\text { difference of } \\
\text { means }\end{array}$} \\
\hline & & Before & After & Before & After & \\
\hline $\begin{array}{l}\text { Decision making } \\
\text { ability }\end{array}$ & $0-30$ & $\begin{array}{l}14.55 \\
(3.96)\end{array}$ & $\begin{array}{l}15.86 \\
(4.03)\end{array}$ & 0.49 & 0.53 & $-12.35^{* *}$ \\
\hline Spending ability & $0-30$ & $\begin{array}{c}8.44 \\
(3.94)\end{array}$ & $\begin{array}{l}10.53 \\
(4.39)\end{array}$ & 0.28 & 0.35 & $-13.25 * *$ \\
\hline Cosmopoliteness & $0-24$ & $\begin{array}{c}4.13 \\
(2.73)\end{array}$ & $\begin{array}{c}4.81 \\
(2.77)\end{array}$ & 0.20 & 0.23 & $-10.48 * *$ \\
\hline Social participation & $0-21$ & $\begin{array}{c}7.88 \\
(3.45)\end{array}$ & $\begin{array}{l}8.85 \\
(3.64)\end{array}$ & 0.26 & 0.30 & $-9.82 * *$ \\
\hline $\begin{array}{l}\text { Access to assets and } \\
\text { resources }\end{array}$ & $0-21$ & $\begin{array}{c}4.61 \\
(3.56)\end{array}$ & $\begin{array}{c}5.59 \\
(3.96)\end{array}$ & 0.22 & 0.27 & $-10.67 * *$ \\
\hline
\end{tabular}

** $\mathrm{P}<0.01$.

N.B. Figure in parentheses indicating standard deviation.

Source: Results of authors' analysis (2007)

Table 3: Stepwise multiple regression analysis shows contribution of five empowerment dimensions to overall

\begin{tabular}{|c|c|c|c|c|}
\hline Model & dimension entered & Multiple R & $\begin{array}{c}\text { Coefficient of } \\
\text { determination } \mathrm{R}^{2}\end{array}$ & $\begin{array}{c}\text { Per cent of } \\
\text { variation expressed }\end{array}$ \\
\hline 1 & $\begin{array}{l}\text { Access to assets and } \\
\text { resources }\end{array}$ & 0.773 & 0.598 & 59.8 \\
\hline 2 & Decision making ability & 0.921 & 0.848 & 25.0 \\
\hline 3 & Spending ability & 0.958 & 0.918 & 6.0 \\
\hline 4 & Social participation & 0.981 & 0.962 & 4.4 \\
\hline 5 & Cosmopoliteness & 1.000 & 1.000 & 3.8 \\
\hline
\end{tabular}

Source: Results of authors' analysis (2007)

Table 4: Categories of rural women according to their status of overall empowerment before and after participation in aquaculture program

\begin{tabular}{lccccc}
\hline \multirow{2}{*}{ Categories and score range } & \multicolumn{2}{c}{ Percentage $(\mathrm{N}=200)$} & Mean and std. dev. & t-statistic \\
\cline { 2 - 4 } & Before & After & Before & After & \\
\hline Very low empowerment (up to 21) & 6.0 & 3.0 & & \\
Low empowerment (22 to 42) & 59.5 & 41.0 & 39.60 & 45.62 & $-16.44^{* *}$ \\
Medium empowerment (43 to 84) & 34.0 & 55.5 & $(11.86)$ & $(12.78)$ & \\
High empowerment (Above 84) & 0.5 & 0.5 & & \\
\multicolumn{1}{c}{ Total } & 100 & 100 & & \\
\hline
\end{tabular}

$* * \mathrm{P}<0.01$.

N.B. Figure in parentheses indicating standard deviation.

Source: Results of authors' analysis (2007)

Data presented in table 4 indicates that there was a clear improvement of rural women in regards to their empowerment status during participation in the DSAP aquaculture program. The table reveals that the percentage of respondents having 'very low' and 'low' empowerment decreased during their participation in aquaculture activities, while an increase was identified in the number of cases of 'medium' empowerment.
The mean empowerment scores before participation (39.60) and after participation (45.62) clearly indicate this improvement and this is further supported by a significant t-value of $-16.44 * *$ in the $\mathrm{t}$ test. However, no women in the study area were elevated to a 'high' level of empowerment. This finding might represent the reality of rural Bangladesh, where, 
in general, levels of female empowerment still remain below expectation. Indeed, although there was improvement in overall empowerment scores over the time scale of the project, they were still not very high overall. The average score before the project started indicates 'average to low' empowerment, while the average empowerment score after the project finished indicates a 'medium' level of empowerment.

Salient features of the selected traits of the rural women: Salient features of the ten selected traits of the respondents have been presented in table 5. The result presented in the table show that the respondents were, in average, quite young. The average education level was low with $33.5 \%$ of the respondents being illiterate and without any formal education. Indeed only $7.5 \%$ had been in education for 12 years (the requirement for university enrolment). This is quite common in any rural area of Bangladesh, where women have less exposure to educational facilities. The average family size (6.94) was quite large; in fact it was even higher than the national average of 5.61 ${ }^{[11]}$. Approximately half $(47.5 \%)$ of the rural women had large families with more than six members, while only $17 \%$ had small families of up to four members.

The average farm size of the rural women (1.39 ha) was considerably higher than the national average of 0.43 ha $^{[11]}$. The reason behind the finding is the reality that, in rural Bangladesh families that have their own pond are not generally poor and so often have large farms. In fact aquaculture is being practiced by the households having larger farm areas and ponds. The average pond size ( $0.25 \mathrm{ha})$ does suggests that the respondents' families possessed small ponds but this was the case what was exactly expected since the respondent families were the primary target population of the study.

Table 5: Salient features of the rural women's selected characteristics

\begin{tabular}{|c|c|c|c|c|c|}
\hline \multirow[t]{2}{*}{ Characteristics } & \multirow[t]{2}{*}{ Unit of measurement } & \multicolumn{2}{|c|}{ Score range } & \multirow[t]{2}{*}{ Mean } & \multirow{2}{*}{$\begin{array}{l}\text { Standard } \\
\text { deviation }\end{array}$} \\
\hline & & Possible & Observed & & \\
\hline Age & years & unknown & $18-65$ & 34.02 & 10.08 \\
\hline Education & Year of schooling & $0-16$ & $0-16$ & 4.23 & 4.30 \\
\hline Family size & Number & unknown & $2-18$ & 6.94 & 2.97 \\
\hline Family farm size & Hectare & unknown & $0.10-7.87$ & 1.39 & 1.18 \\
\hline Area under aquaculture & Hectare & unknown & $0.04-3.45$ & 0.25 & 0.36 \\
\hline Extension media contact & Scale score & $0-51$ & $0-26$ & 8.74 & 4.06 \\
\hline Training exposure & Days & unknown & $0-180$ & 8.74 & 4.06 \\
\hline Aquaculture knowledge & Scale score & $0-30$ & $10-30$ & 21.99 & 4.28 \\
\hline Family annual income & '000 Taka* & unknown & $12-500$ & 120.2 & 88.85 \\
\hline Participation in aquaculture & Scale score & $0-30$ & $0-27$ & 8.32 & 8.63 \\
\hline
\end{tabular}

*1 US\$ = 65 Bangladeshi Taka (BDT)

Source: Authors' survey (2004)

Table 6: Relationship between rural women's empowerment and selected characteristics

\begin{tabular}{lc}
\hline \multicolumn{1}{c}{ Independent variables } & Correlation coefficient (r) with 198 df \\
\hline Age & -0.52 \\
Education & $0.190^{*}$ \\
Family size & 0.038 \\
Family farm size & 0.006 \\
Area under aquaculture & 0.063 \\
Extension media contact & $0.309 * *$ \\
Training exposure & $0.253^{* *}$ \\
Knowledge in aquaculture & $0.156^{*}$ \\
Family annual income & 0.136 \\
Participation in aquaculture & $0.387^{* *}$ \\
\hline$*$ P $<0.05$ and $* *$ P $<0.01$ with 198 d.f. & \\
Source: Results of authors' analysis $(2007)$ &
\end{tabular}


Table 7: Stepwise multiple regression analysis showing variation of women's empowerment score explained by different factors

\begin{tabular}{clccc}
\hline Model & \multicolumn{1}{c}{ Variable entered } & Multiple R & $\begin{array}{c}\text { Coefficient of } \\
\text { determination } \mathrm{R}^{2}\end{array}$ & $\begin{array}{c}\text { Per cent of variation } \\
\text { expressed }\end{array}$ \\
\hline 1 & $\begin{array}{l}\text { Participation in } \\
\text { aquaculture }\end{array}$ & 0.386 & 0.149 & 14.9 \\
2 & Education & 0.489 & 0.239 & 9.0 \\
3 & $\begin{array}{l}\text { Extension media } \\
\text { contact }\end{array}$ & 0.528 & 0.279 & 4.0 \\
4 & Training exposure & 0.551 & 0.304 & 2.5 \\
\hline
\end{tabular}

Source: Results of authors' analysis (2007)

The average aquaculture participation score $(8.32$ against a possible maximum value of 90 ) was very low. The average extension media contact score (8.74 against a possible maximum value of 51) was also relatively low. This result is not unexpected since, in rural areas of Bangladesh, there are only small numbers of women who can go outside their households and interact with other people (particularly men) outside of their own families. However, the study also revealed that extension work among the women was not properly emphasized by the NGO field agents, which, should not have occurred and was not expected.

Relationship between women empowerment and their selected traits: Relationships between the selected independent variables and a women's extent of empowerment were determined by Pearson's product moment correlation coefficient $(\mathrm{r})$, which is presented in table 6 (previous page).

The results show that five variables had significant positive relationships with the women's extent of empowerment through participation in the DSAP aquaculture program. Furthermore, apparently important variables such as education, family farm size, area under aquaculture and family annual income did not in fact show any significant relationship with women's empowerment.

A significant relationship was found between the women's education and their empowerment and this implies that education enhances a women's empowerment, both in family and society. It increases a woman's understanding and awareness of the situation in which she lives, as well as increases her cognitive and psychological realm of empowerment. This is supported by a study conducted by Ahmed ${ }^{[12]}$ which also concluded that education gives women 'a voice' against social and political injustice, and that they will have more freedom when they have more education and knowledge. This finding is further supported by some other works conducted in Bangladesh ${ }^{[1,13]}$.
Extension media contact, training exposure and knowledge are among the most important factors that increase one's understanding of innovations and influence their process of decision making towards adoption of new technologies and processes ${ }^{[14]}$. As all these factors can make a woman confident and skilful in using technology, they logically also increase her level of empowerment.

The significant and positive relationship between women's participation in aquaculture and their extent of empowerment implies that the empowerment status of women can increase with their increased participation in aquaculture activities. As aquaculture is a relatively profitable income generating activity, women participating in it gain more control of the economic and social returns from it. This makes them self-reliant and enhances their empowerment status within the family as well as in society in general.

The multiple regression analysis (table 7) revealed that only four independent variables were significant predictors of women's empowerment. These were; participation in aquaculture, education, extension media contact and exposure to training. The results show that $30.4 \%$ of the variation in a women's empowerment can be accounted by the combined effect of these four independent variables, with participation in aquaculture and education accounting for $14.9 \%$ and $9 \%$ of the variation respectively.

\section{CONCLUSION}

Based on the results reported in this study, it can be concluded that the empowerment status of rural women in Bangladesh can be significantly improved by increasing their involvement in an income generating activity such as aquaculture, providing the income goes to them and not just their husbands. The major problem is that the general level of participation in aquaculture by women remains far below expectation. Therefore there exists huge scope to involve women in 
aquaculture. Factors such as education, extension contact and exposure to training can all increase a woman's technical knowledge, which in turn will increase her participation in aquaculture. Appropriate extension strategies and motivational drives can be instrumental to achieve this goal. If the government and other development partners work together in addressing these issues, they could better address the needs of rural women in Bangladesh.

\section{ACKNOWLEDGEMENT}

The authors gratefully acknowledge the financial support for the study by USAID through the Development of Sustainable Aquaculture Project, which was implemented by the WorldFish Center, Bangladesh and the South Asia office.

\section{REFERENCES}

1. Biswas, T.K. 2002. Women's empowerment and demographic change. $\mathrm{PhD}$ thesis, Department of Statistics, Jahangirnagar University, Dhaka.

2. UNDP. 2005. Human Development Reports 2005. United Nations Development Program. Washington D.C.

3. Lovell, C.H. 1991. Breaking the Cycle of Poverty: The BRAC Strategy. Kumarian Press, Bloomfield, USA.

4. DSAP. 2003. DSAP-NGO Directory 2003. Work paper no. 2003/15, Development of Sustainable Aquaculture Project and WorldFish Center, Dhaka.

5. Stromquist, N. P. 1995. "The theoretical and practical bases for empowerment." In: C. MedelAnonuevo. (ed.). Women, Education and Empowerment: Pathways Towards Autonomy.
(Report of the international seminar held at UIE, Hamburg, Germany), UNESCO, Paris.

6. Jejeebhoy, S.J. 1995. Women's Education, Autonomy and Reproductive Behaviour: Experiences from Four Developing Countries. Clarendon Press, Oxford.

7. CIDA (Canadian International Development Agency). 1996. Guide to Gender Sensitive Indicators. CIDA, Canada.

8. Kishor, S. 2000. "Empowerment of women in Egypt and links to the survival and health of the infants." In: H. Presser and G. Sen. (eds.). Women's Empowerment and Democratic Processes: Moving Beyond Cairo. New York: Oxford University Press.

9. Hossain, S.M.A. 1992. Patterns and determinants of adoption of farm practices: some evidence from Bangladesh. Agricultural Systems. 38, 1-15.

10. Loomis, C.P. \& Beegle, J.A. 1957. Rural Sociology: The Strategy of Change. Prentice-Hall, Inc., Englewood Cliffs.

11. BBS (Bangladesh Bureau of Statistics). 2005. Statistical Yearbook of Bangladesh 2004. Bangladesh Bureau of Statistics, Ministry of Planning, Government of the People's Republic of Bangladesh, Dhaka.

12. Ahmed, Z.N. 2003. Mapping rural women's perspectives on non-formal education experiences. In: Ali, et al. (eds.). Development Issues of Bangladesh - II. The University Press Limited, pp. 115-156.

13. Sarker, T. 2005. Empowerment of women beneficiaries through involvement in income generating activities under CONCERN. MS Thesis, Department of Agricultural Extension Education, Bangladesh Agricultural University, Mymensingh, Bangladesh.

14. Rogers, E.M. 1995. Diffusion of Innovations. $4^{\text {th }}$ edn. The Free Press, New York. 